\title{
16. ABUNDANCE AND ISOTOPIC COMPOSITION OF ORGANIC AND INORGANIC SULFUR SPECIES IN LAMINATED AND BIOTURBATED SEDIMENTS FROM HOLE 893A, SANTA BARBARA BASIN ${ }^{1}$
}

\author{
Volker Brüchert, ${ }^{2}$ Lisa M. Pratt, ${ }^{2}$ Thomas F. Anderson, ${ }^{3}$ and Stephen R. Hoffmann ${ }^{3}$
}

\begin{abstract}
Organic carbon and total sulfur have been analyzed in 29 core samples from Ocean Drilling Program (ODP) Hole 893A spanning $191 \mathrm{~m}$ of marine sediment that record variable paleoceanographic conditions in the Santa Barbara Basin during the past 160,000 yr. Sulfur isotope ratios have been determined for six species of sulfur (pyrite S, acid-volatile S, elemental S, kerogen S, bitumen S, and sulfate S) in order to establish an isotope budget for sulfur in laminated and nonlaminated/bioturbated sediments. Variations in the relative abundance of specific sulfur species correlate with sedimentological properties in the cores. Abundances of total, acid-volatile, and pyrite sulfur are highest in laminated intervals. Abundances of elemental sulfur, bitumen, and kerogen sulfur are higher in nonlaminated samples and show a strong negative correlation with abundances of pyrite sulfur. Sulfur isotopic compositions of pyrite generally are depleted in ${ }^{34} \mathrm{~S}$ and vary between $-39 \%$ and $-15 \%$ versus the Cañon Diablo Troilite standard (CDT). The highest isotopic ratios for pyrites occur in nonlaminated samples. The isotopic composition of acid-volatile sulfur is consistently more enriched in ${ }^{34} \mathrm{~S}$ than pyrite sulfur, and is not well correlated with the isotopic variation of pyrite sulfur. Isotopic compositions of elemental sulfur vary between $-22 \%$ and $+14 \%$ vs. CDT with the lowest isotopic values in nonlaminated samples and the highest $\delta$-values in laminated samples. Isotopic compositions of bitumen and kerogen sulfur range between $-2 \% o$ and $6 \%$ vs. CDT suggesting formation of organic sulfur either later than mineral sulfur or with involvement of different fractionation effects related to sulfur oxidation and incorporation into organic matter.

Levels of benthic oxygenation affected both partitioning and isotopic fractionation of sulfur during early diagenesis. Higher abundances of elemental and organically bound sulfur in bioturbated and structureless sediments may be related to higher concentrations of geologically transient species such as polysulfides, polythionates, and thiosulfate. Calculation of the isotopic composition of total sulfur and assessment of the fraction of sulfur retained in the sediments indicates that, with one possible exception, never more than $60 \%$ of dissolved sulfate was retained in the sediment. Sulfate reduction rates did not exceed rates of sulfate supply. Thus, sulfur cycling in the marine sediment recovered from ODP Hole 893A is not analogous to the sulfatelimited system in the Miocene Monterey Formation.
\end{abstract}

\section{INTRODUCTION}

Speciation, abundance, and isotopic composition of sulfur-containing diagenetic phases result from a complex system that involves, among other controlling variables, the degree of benthic oxygenation. Relationships between organic carbon and pyrite sulfur or total sulfur have been widely used in modern and ancient marine sediments as indicators of the relative oxygenation of paleoenvironments (e.g., Raiswell and Berner, 1985; Raiswell et al., 1988; Dean and Arthur, 1989; Bein et al., 1990; Middelburg, 1991). A number of studies, however, have shown that carbon/sulfur plots provide useful information but have the potential for multiple interpretations (Dean and Arthur, 1989; Bein et al., 1990; Zaback and Pratt, 1992). Various recent studies (Kohnen et al., 1990; Mossmann et al., 1991; Ferdelman et al., 1991; Schimmelmann and Kastner, 1993; Zaback and Pratt, 1992; Aplin and Macquaker, 1993; Raiswell et al., 1993) have emphasized the importance of organic matter and elemental sulfur as important early diagenetic sinks for reduced and partially oxidized sulfur in marine sediments. Incorporation of sulfur into organic matter appears to be most favorable under conditions where partially ox-

'Kennett, J.P., Baldauf, J.G., and Lyle, M. (Eds.), 1995. Proc. ODP, Sci. Results, 146 (Pt. 2): College Station, TX (Ocean Drilling Program).

${ }^{2}$ Department of Geological Sciences, Indiana University, Bloomington, IN 47405. U.S.A.

Department of Geology, University of Mlinois at Urbana-Champaign, Urbana, IL 61801 , U.S.A. idized aqueous species of sulfur such as polysulfides may be present (Mossmann et al., 1991; Raiswell et al., 1993; Aplin and Macquaker, 1993). Consequently, changes in relative abundances of mineral, organic, and elemental sulfur may be used to interpret past pore-water conditions and to infer past benthic environments.

A major obstacle to interpretation of paleoenvironments based on the abundance of diagenetic products comes from uncertainty about the relative timing of formation of individual sulfur compounds. Formation of diagenetic sulfur compounds can continue long after the deposition of a sediment or start above the sediment-water interface. Sulfur products represent the cumulative effects of water-column, depositional, and diagenetic conditions and cannot be used as a simple paleoenvironmental indicator. Constraints on the timing of formation of sulfur species can be provided by stable sulfur isotopic compositions (Goldhaber and Kaplan, 1980; Chanton et al., 1987; Mossmann et al., 1991; Zaback and Pratt, 1992). Although details of the early depositional and diagenetic sulfur cycle are not exactly understood, the isotopic composition of individual sulfur species may be used to generally evaluate the genesis of sulfur species, sequence of incorporation, and conditions present in the benthic environment during formation of sulfur products.

The current study was initiated to provide additional geochemical evidence for conventional geochemical, sedimentological, paleontological, and palynological studies of climatic and paleoceanographic variability recorded in Hole 893A. Carbon/sulfur relationships, relative abundances of six sulfur species (pyrite S, acid-volatile S, elemental S, kerogen S, bitumen S, and sulfate S), as well as the isotope 
Table 1. General lithologic description of samples studied, Hole 893A.

\begin{tabular}{|c|c|}
\hline $\begin{array}{l}\text { Core, section, } \\
\text { interval }(\mathrm{cm})\end{array}$ & General description \\
\hline 146-893A- & \\
\hline IH-1, 82-98 & Diatom nannofossil silty clay; well-laminated \\
\hline $\mathrm{IH}-4,82-97$ & Diatom nannofossil silty clay; indistinctly laminated \\
\hline $2 \mathrm{H}-3,83-99$ & Diatom nannofossil silty clay; with traces of lamination \\
\hline $2 \mathrm{H}-7,62-80$ & Diatom nannofossil silty clay: well-laminated \\
\hline $3 \mathrm{H}-3,73-88$ & Diatom nannofossil silty clay; structureless \\
\hline $3 \mathrm{H}-4,82-94$ & Diatom nannofossil silty clay; well-laminated \\
\hline $4 \mathrm{H}-4,4-16$ & Diatom nannofossil silty elay (light olive-grey brown, mottled and bioturbated): massive and unlaminated \\
\hline $5 \mathrm{H}-5,71-77$ & Nannofossil silty clay; unlaminated \\
\hline $6 \mathrm{H}-3,83-98$ & Olive grey silty clay \\
\hline $6 \mathrm{H}-5,112-128$ & Olive grey silty clay; from laminated bottom part \\
\hline $7 \mathrm{H}-3,103-128$ & Diatom silty clay; interbedded sand layers \\
\hline $7 \mathrm{H}-5,61-74$ & Diatom silty clay above sand layer \\
\hline $9 \mathrm{H}-4.71-85$ & Diatom silty clay; structureless \\
\hline $10 \mathrm{H}-4,45-59$ & Silty clay; structureless \\
\hline $12 \mathrm{H}-3,90-102$ & Silty clay with bioturbation \\
\hline $13 \mathrm{H}-6.44-55$ & Diatom silty clay; structureless or weak mottling and bioturbation \\
\hline $14 \mathrm{H}-2,45-56$ & Diatom silty clay; structureless or weak bioturbation and mottling \\
\hline $15 \mathrm{H}-3,92-104$ & Silty clay: somewhat laminated \\
\hline $15 \mathrm{H}-5,117-129$ & Silty clay: weakly laminated package \\
\hline $16 \mathrm{H}-2,22-33$ & Diatom grey silty clay and clayey silt: well-laminated \\
\hline $16 \mathrm{H}-3,26-40$ & Diatom grey silty clay and clayey silt: well-laminated \\
\hline $17 \mathrm{H}-3,110-122$ & Silty clay; structureless \\
\hline $18 \mathrm{H}-4.84-96$ & Clayey silt to silty clay: laminated package \\
\hline $18 \mathrm{H}-5,81-93$ & Clayey silt to silty clay; laminated package, borders structureless part below \\
\hline $19 \mathrm{H}-2,130-141$ & Silty clay to clayey silt; laminated package \\
\hline $19 \mathrm{H}-5,66-77$ & Silty clay to clayey silt with disseminated pyrite: structureless \\
\hline $20 \mathrm{H}-4,41-53$ & Silty to clayey silt: with shell-bearing bed; structureless \\
\hline $21 \mathrm{H}-2,134-146$ & Silty clay; structureless: with shell-bearing beds \\
\hline $21 \mathrm{H}-4,124-136$ & Silty clay; well-laminated package \\
\hline
\end{tabular}

abundances of these sulfur species are used to reconstruct depositional and diagenetic conditions during the last $160 \mathrm{k} . \mathrm{y}$. in this California borderland basin. Sediments from Hole 893 A provide an opportunity to test whether relative abundance of sulfur species, carbon/sulfur relationships, and isotopic composition of individual sulfur species are useful indicators of environmental conditions.

\section{GENERAL LITHOLOGY AND PETROGRAPHY}

Sediments at Site 893 represent an upper Quaternary sequence of marine deposits deposited at high sedimentation rates of $0.8-1.1 \mathrm{~cm} /$ yr (Soutar and Crill, 1977). The major lithologies in Hole 893A are diatom nannofossil silty clays and olive grey silty clays (Table 1). Sedimentary fabrics in Hole 893A alternate between laminated and bioturbated/structureless, which are inferred to reflect changing oxygen contents in the benthic environment. With the exception of turbiditic sandstone beds, the lithologic variation through the cored interval involves repetition of those two major lithologies. The cored interval is recognized as one lithostratigraphic unit and is subdivided into six subunits primarily based on the degree of lamination (Kennett, Baldauf, et al., 1994). Based on preliminary studies of pollen content and biostratigraphy of planktonic foraminifera, the sequence at Hole 893A extends from near the base of Isotope Stage 6 until the present day and includes two glacial and two interglacial episodes (Kennett, Baldauf, et al., 1994).

Smear slide observations show that pyrite occurs both as dispersed framboids and aggregate framboids with sizes up to $200 \mu \mathrm{m}$. Single, equant crystals of pyrite have varying grain sizes between 25 $\mu \mathrm{m}$ and $80 \mu \mathrm{m}$. Frequently, pyrite crystals and framboids are found inside the chambers of foraminifers and diatom frustules or embedded in glauconite and other sheet silicates. The smear slides showed no clear change in pyrite grain size or proportion of framboids relative to equant crystals with depth or sediment texture.

\section{MATERIALS AND METHODS}

Cores of Hole $893 \mathrm{~A}$ were initially stored in air at ambient temperatures for at least $48 \mathrm{hr}$ prior to transfer to cold storage. During this period, some oxidation of partially and fully reduced dissolved sulfur species and metastable acid-volatile monosulfides may have occurred. Oxidation could have decreased the abundance of acid-volatile sulfur, decreased or increased the abundance of elemental sulfur, and increased the relative abundance of sulfate sulfur. In our laboratory, samples were stored frozen in air prior to preparation for analysis. Despite the potential for oxidation, a characteristic and consistent distribution of sulfur species with distinct isotopic signatures was recognized.

Table 1 lists stratigraphic position, age, general lithological character, and sedimentary textures of the sediments used in this study. Sediment ages were adopted from Ingram and Kennett (this volume). The samples are distributed over the length of core recovered from Hole 893A. At least one sample was taken from each core. A smear slide was prepared for each sample to obtain information on grain size, shape of opaque crystals (mostly pyrite), and stratigraphic variation of petrographic characteristics.

Samples were received sealed in plastic bags and were kept frozen until they were thawed and dried at room temperature just prior to analysis. Organic carbon and total sulfur were determined on 29 samples using a $\mathrm{LECO}^{\oplus} \mathrm{C} / \mathrm{S}-244$ induction furnace. Total sulfur was determined directly from dried whole-rock powder. Measured values of total sulfur include pore-water sulfur species precipitated during drying. Organic carbon was determined by decalcifying about $0.5 \mathrm{~g}$ of whole-rock powders in $100 \mathrm{~mL} 1 \mathrm{~N} \mathrm{HCl}$ at $25^{\circ} \mathrm{C}$ overnight. Insoluble residues were concentrated on glass-fiber filters (Whatman $\mathrm{GF} / \mathrm{C}$ ), washed with distilled water and dried at $60^{\circ} \mathrm{C}$ prior to analysis. Dried residue and glass-fiber filter were combusted together. An extraction scheme similar to the one described in Zaback and Pratt (1992) was applied to 10 samples in order to separate pyrite and acid-volatile, el- 


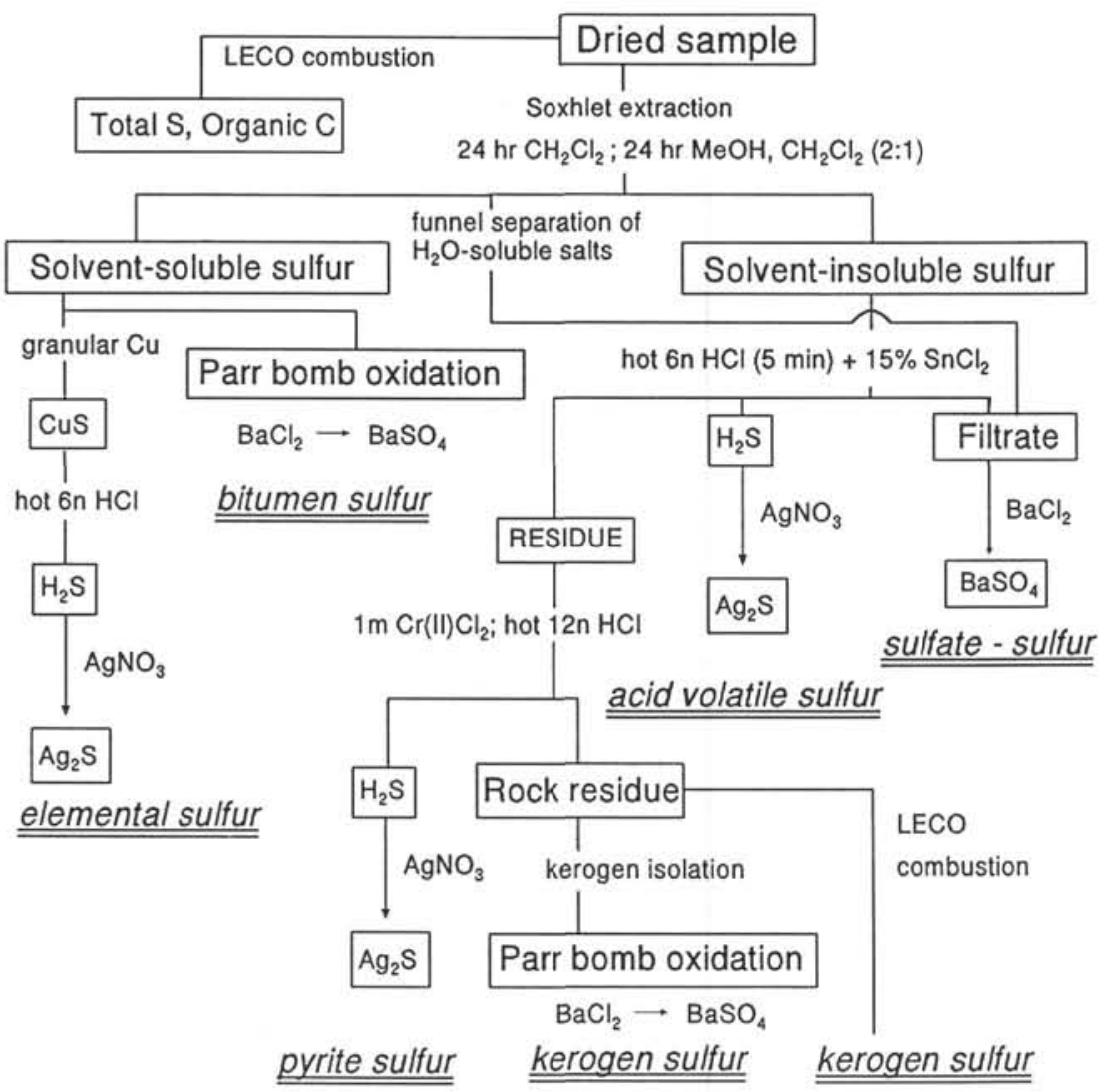

Figure 1. Flow chart of extraction procedure for sulfur species. emental, bitumen, kerogen, and sulfate sulfur. For the sulfur extraction, 15-35 g of air-dried sediment was ground in an agate mortar and pestle and used for the extraction. A flow chart summarizes the extraction scheme (Fig. 1). Abundances of extracted sulfur species were determined gravimetrically and recalculated to weight percent relative to dried whole rock. Weighing precision based on duplicates is better than $\pm 0.1 \mathrm{mg}$.

$\mathrm{SO}_{2}$ gases for isotope analysis were obtained by combusting the precipitates of $\mathrm{BaSO}_{4}$ or $\mathrm{Ag}_{2} \mathrm{~S}$, respectively, at $1025^{\circ} \mathrm{C}$ for $20-30$ minutes on a vacuum line. $\mathrm{A} 1: 1$ weight mixture of $\mathrm{V}_{2} \mathrm{O}_{5} / \mathrm{SiO}_{2}$ was used as the oxidant. Native copper turnings cleaned three times with IN HCl and dichloromethane were added to sample charges to remove excess oxygen formed during combustion and prevent formation of $\mathrm{SO}_{3}$ gas. Purification of gas was performed by cryogenic distillation using a temperature-controlled gas trap immersed in liquid nitrogen. $\mathrm{CO}_{2}$ was distilled off between $-187^{\circ} \mathrm{C}$ and $-145^{\circ} \mathrm{C} . \mathrm{SO}_{2}$ was released subsequently between $-145^{\circ} \mathrm{C}$ and $-95^{\circ} \mathrm{C}$ and isolated in a second trap. $\mathrm{SO}_{2}$ gas was analyzed on a Nuclide 6-60 mass spectrometer. Results are reported in standard per mil deviation relative to Cañon Diablo Troilite (CDT). Gas samples smaller than $5 \mathrm{M}$ sulfur could not be analyzed. Precision of isotope analyses for replicate samples and lab standards was $0.25 \%$ or better.

\section{RESULTS AND DISCUSSION}

\section{Organic Carbon/Total Sulfur Geochemistry}

Samples examined are enriched in total sulfur relative to organic carbon when compared to the Holocene Marine Reference (HMR) line (Sweeney and Kaplan, 1980; Raiswell and Berner, 1985), but there is good correlation of carbon and sulfur in structureless, bioturbated, and nonlaminated samples $(r=0.63)$ (Fig. 2, Table 2). A regression line leading through the origin for the structureless,

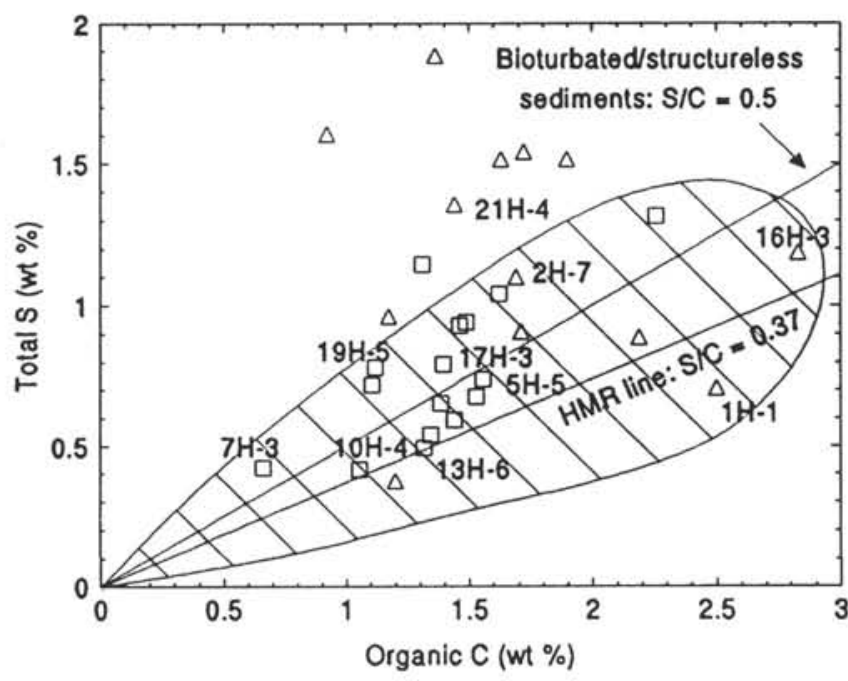

Figure 2. Organic carbon/total sulfur plot for 29 samples from Hole 893A, separated according to general lithology. Open squares represent bioturbated and structureless sediments and open triangles represent laminated sediments. A linear regression on bioturbated sediments gave a line with a slope of 0.5 and a correlation coefficient of 0.63 . For reference, the Holocene Marine Reference (HMR) line has a slope of 0.37 (Goldhaber and Kaplan, 1974). Most of the samples from Hole 893A plot within the envelope described by samples used to define the HMR line, suggesting normal marine depositional conditions. 
Table 2. Organic carbon and total sulfur contents in samples from Hole 893A.

\begin{tabular}{|c|c|c|c|c|}
\hline $\begin{array}{l}\text { Core, section, } \\
\text { interval }(\mathrm{cm})\end{array}$ & $\begin{array}{l}\text { Depth } \\
\text { (mbsf) }\end{array}$ & $\begin{array}{l}\text { Age } \\
\text { (ka) }\end{array}$ & $\begin{array}{l}\text { Organic C } \\
(\mathrm{wt} \%)\end{array}$ & $\begin{array}{l}\text { Total S } \\
(w t \%)\end{array}$ \\
\hline \multicolumn{5}{|l|}{$146-893 \mathrm{~A}$} \\
\hline IH-1, 82-98 & 0.9 & 0.5 & 2.50 & 0.71 \\
\hline $1 \mathrm{H}-4,82-97$ & 5.4 & 3.1 & 2.19 & 0.89 \\
\hline $2 \mathrm{H}-3,83-99$ & 10.4 & 6.3 & 1.71 & 0.91 \\
\hline $2 \mathrm{H}-7,62-80$ & 15.7 & 9.7 & 1.69 & 1.10 \\
\hline $3 \mathrm{H}-3,73-88$ & 19.8 & 12.4 & 1.53 & 0.41 \\
\hline $3 \mathrm{H}-4,82-94$ & 21.2 & 13.4 & 1.31 & 1.32 \\
\hline $4 \mathrm{H}-4,4-16$ & 29.6 & 19.1 & 1.46 & 0.93 \\
\hline $5 \mathrm{H}-5,71-77$ & 41.1 & 27.0 & 1.56 & 0.74 \\
\hline $6 \mathrm{H}-3,83-98$ & 47.8 & 32.2 & 1.39 & 0.65 \\
\hline $6 \mathrm{H}-5,112-128$ & 50.9 & 34.4 & 1.17 & 0.96 \\
\hline $7 \mathrm{H}-3,103-128$ & 55.9 & 38.1 & 0.66 & 0.42 \\
\hline $7 \mathrm{H}-5,61-74$ & 58.2 & 39.7 & 1.35 & 0.54 \\
\hline $9 \mathrm{H}-4,7 \mathrm{I}-85$ & 77.4 & 54.0 & 1.44 & 0.59 \\
\hline $10 \mathrm{H}-4,45-59$ & 87.4 & 62.4 & 1.06 & 0.42 \\
\hline $12 \mathrm{H}-3,90-102$ & 105.2 & 80.7 & 1.62 & 1.04 \\
\hline $13 \mathrm{H}-6,44-55$ & 117.0 & 90.7 & 1.32 & 0.49 \\
\hline $14 \mathrm{H}-2,45-56$ & 122.5 & 96.5 & 2.26 & 1.31 \\
\hline $15 \mathrm{H}-3.92-104$ & 133.7 & 108.5 & 1.90 & 1.52 \\
\hline $15 \mathrm{H}-5,117-129$ & 137.0 & 112.1 & 1.63 & 1.52 \\
\hline $16 \mathrm{H}-2,22-33$ & 40.9 & 116.2 & 0.92 & 160 \\
\hline $16 \mathrm{H}-3.26-40$ & 142.4 & 116.7 & 2.83 & 1.19 \\
\hline $17 \mathrm{H}-3,110-122$ & 153.1 & 125.2 & 1.40 & 1.11 \\
\hline $18 \mathrm{H}-4.84-96$ & 163.8 & 133.2 & 1.36 & 1.88 \\
\hline $18 \mathrm{H}-5,81-93$ & 165.2 & 134.5 & 1.20 & 0.37 \\
\hline $19 \mathrm{H}-2,130-141$ & 170.7 & 139.5 & 1.72 & 1.54 \\
\hline $19 \mathrm{H}-5.66-77$ & 174.5 & 142.9 & 1.12 & 0.78 \\
\hline $20 \mathrm{H}-4,41-53$ & 182.2 & 149.8 & 1.10 & 0.72 \\
\hline $21 \mathrm{H}-2,134-146$ & 189.2 & 156.1 & 1.49 & 0.94 \\
\hline $2 \mathrm{IH}-4,124-136$ & 192.3 & 158.9 & 1.44 & 1.35 \\
\hline
\end{tabular}

bioturbated and nonlaminated samples has a slope of 0.50 , which is slightly higher than the average sulfur/carbon ratio of samples used to plot the HMR line. Sulfur/carbon ratios of $0.37 \pm 0.15$ in Holocene marine sediments from continental shelves and slopes generally are interpreted to represent well-oxygenated benthic environments where reactive organic carbon contents limit sulfate reduction and reactive $\mathrm{Fe}$ is present in excess. In such environments there is a consistent relation among sulfate reduction rates, accumulation rates of reactive detrital $\mathrm{Fe}$, and retention of reduced sulfur (Berner, 1984; Raiswell and Berner, 1985; Raiswell et al., 1988; Canfield, 1989).

Abundances of organic carbon and total sulfur vary substantially within the laminated samples from Hole 893A (Table 2). Figure 2 shows that half of the laminated sediments are enriched in total sulfur relative to organic carbon, whereas the other half plot within the envelope of Holocene marine sediments. Relative enrichment in total sulfur or pyrite sulfur with respect to organic carbon and a positive sulfur intercept has been interpreted to indicate euxinic benthic conditions, sulfidic bottom waters, and formation of sulfide minerals in the water column (Raiswell and Berner, 1985). Alternatively, a larger fraction of metabolizable relative to non-metabolizable organic carbon compared to the other sediments can result in higher sulfur/carbon ratios (Hieshima and Pratt, 1991). Variation in the hydrogen index $(\mathrm{HI})$ values of bulk organic matter in samples studied by Stein and Rack (this volume) support an interpretation of changing quantities of terrigenous, marine, and bacterial organic matter.

Enhanced contribution of readily metabolizable organic matter from marine or bacterial sources may be responsible for the enrichment in sulfur of some laminated sediments. Plotted in stratigraphic profile, organic carbon shows a steady decrease in the uppermost 17 $\mathrm{m}$, possibly attributed to ongoing consumption of readily metabolizable organic matter (Fig. 3). Total sulfur contents are consistently higher in laminated intervals compared to adjacent bioturbated or structureless intervals. Notable also are high sulfur contents between 130 and 145 mbsf that do not correspond with high organic carbon contents. A similar relationship is evident at $160 \mathrm{mbsf}$ and $25 \mathrm{mbsf}$. These peaks in sulfur content are data points that plot in the field above the envelope for Holocene normal marine sediments (Fig. 2).

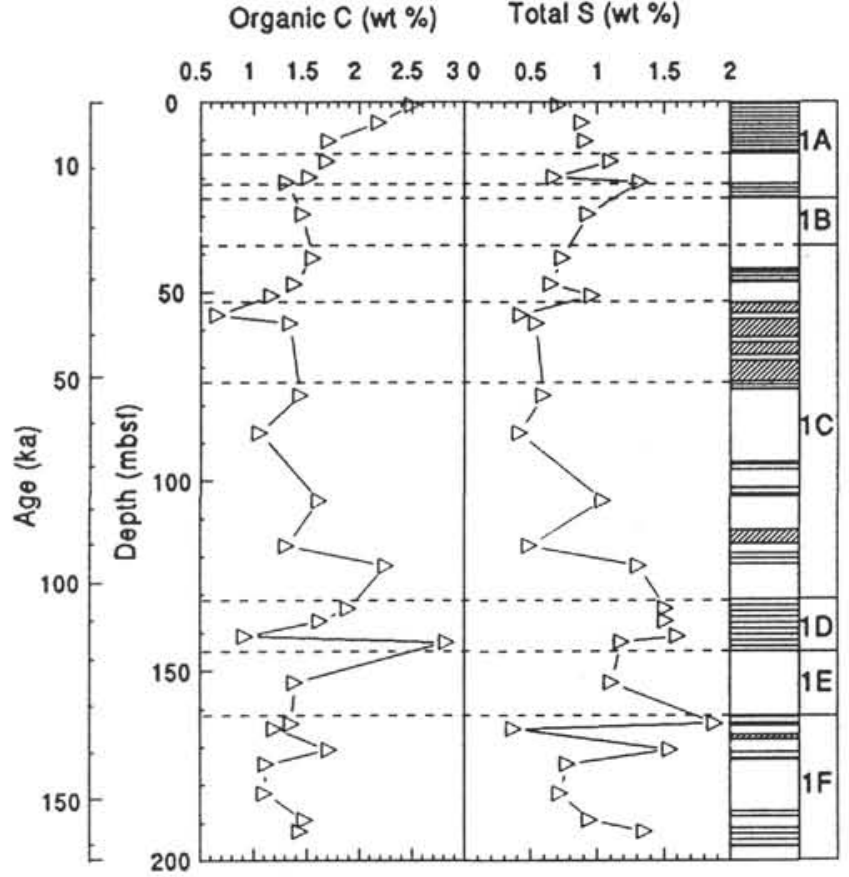

Figure 3. Stratigraphic variation in abundance of organic carbon and total sulfur for 29 sediments of Hole 893A. Columns on the right show variation in sedimentary fabric varying between laminated (laminated pattern) and nonlaminated/structureless sediments (no pattern). Subunit IC contains several sand layers (diagonal line pattern). Division of cored interval into subunits IA through IF was adopted from Kennett, Baldauf, et al. (1994). Age assignments are based on pollen events, biostratigraphy, and ${ }^{14} \mathrm{C}$ chronology (Ingram and Kennett, this volume).

These samples are also characterized by high $\mathrm{HI}$ values for bulk organic matter (Stein and Rack, this volume) suggesting an organic carbon source with a higher fraction of metabolizable organic carbon of either marine or bacterial origin.

\section{Abundances of Sulfur Species}

\section{Pyrite-Organic Carbon-Organic Sulfur-Elemental Sulfur Relationships}

Table $3 \mathrm{~A}$ shows abundances of extracted sulfur species in weight percent relative to bulk sediment. In Table $3 \mathrm{~B}$ the data have been recalculated to percent sulfur species relative to total sulfur. Total yields varied between $76 \%$ and $88 \%$ compared to total sulfur abundances established by LECO $^{\oplus}$ combustion. Low yields may be because of incomplete transport of $\mathrm{H}_{2} \mathrm{~S}$ in the $\mathrm{N}_{2}$ stream, incomplete trapping of $\mathrm{H}_{2} \mathrm{~S}$ in the $\mathrm{AgNO}_{3}$ trap, or from loss of sample on filters.

Abundances of pyrite covary positively with organic carbon contents below $17 \mathrm{~m}$ (Fig. 4A, B). A negative covariance occurs in the uppermost $17 \mathrm{~m}$, possibly related to ongoing formation of pyrite at this stratigraphic interval. Abundances of pyrite are highest in laminated sediments and lowest in bioturbated/structureless sediments. Although there is generally good correlation between abundances of organic carbon and pyrite, ratios of pyrite and organic carbon vary (Fig. 5). Consistently lower ratios of organic carbon to pyrite in interval IC, which is predominantly structureless and bioturbated, and higher ratios of organic carbon to pyrite in intervals $1 \mathrm{~A}$ and ID may indicate differential degrees of sulfur retention as pyrite. Alternatively, varying ratios of organic carbon to pyrite could be the result of changes in the quantity of metabolizable organic carbon.

Abundances of kerogen, bitumen, and elemental sulfur are higher in bioturbated and/or structureless intervals and are negatively corre- 
Table 3. A. Abundances of sulfur species ( $w t \%$ ) relative to bulk sediment, Hole 893A.

\begin{tabular}{lrrrrrrr}
\hline $\begin{array}{c}\text { Core, section, } \\
\text { interval }(\mathrm{cm})\end{array}$ & $\begin{array}{c}\text { Depth } \\
\text { (mbsf) }\end{array}$ & $\begin{array}{c}\text { Pyrite } \\
\text { sulfur }\end{array}$ & $\begin{array}{c}\text { Acid-vol. Elemental } \\
\text { sulfur }\end{array}$ & $\begin{array}{c}\text { Sulfate } \\
\text { sulfur } \\
\text { sulfur }\end{array}$ & $\begin{array}{c}\text { Bitumen } \\
\text { sulfur }\end{array}$ & $\begin{array}{c}\text { Kerogen } \\
\text { sulfur }\end{array}$ \\
\hline 146-893A- & & & & & & & \\
$1 \mathrm{H}-1,82-98$ & 0.9 & 0.475 & 0.048 & 0.014 & 0.117 & 0.012 & 0.047 \\
$2 \mathrm{H}-7,62-80$ & 15.6 & 0.598 & 0.160 & & 0.134 & 0.008 & 0.049 \\
$5 \mathrm{H}-5,71-77$ & 41.1 & 0.307 & 0.202 & 0.006 & 0.114 & 0.004 & 0.040 \\
$7 \mathrm{H}-3,103-128$ & 55.9 & 0.109 & 0.102 & 0.056 & 0.021 & 0.004 & 0.037 \\
$10 \mathrm{H}-4,45-59$ & 87.4 & 0.145 & 0.040 & 0.040 & 0.072 & 0.008 & 0.032 \\
$13 \mathrm{H}-6,44-55$ & 117.0 & 0.201 & 0.095 & 0.013 & 0.090 & 0.011 & 0.042 \\
$16 \mathrm{H}-3,26-40$ & 142.4 & 0.853 & 0.094 & 0.005 & 0.058 & 0.009 & 0.053 \\
$17 \mathrm{H}-3,110-122$ & 153.1 & 0.435 & 0.084 & 0.002 & 0.140 & 0.008 & 0.039 \\
$19 \mathrm{H}-5,66-77$ & 174.5 & 0.196 & 0.213 & 0.025 & 0.002 & 0.004 & 0.068 \\
$21 \mathrm{H}-4,124-136$ & 192.3 & 0.329 & 0.400 & 0.006 & 0.238 & 0.007 & 0.040 \\
\hline
\end{tabular}

B. Abundances of sulfur species in weight percent relative to total sulfur, Hole 893A.

\begin{tabular}{|c|c|c|c|c|c|c|c|c|}
\hline $\begin{array}{l}\text { Core, section, } \\
\text { interval }(\mathrm{cm})\end{array}$ & $\begin{array}{l}\text { Depth } \\
\text { (mbsf) }\end{array}$ & $\begin{array}{l}\text { Pyrite } \\
\text { sulfur }\end{array}$ & $\begin{array}{l}\text { Acid-vol. } \\
\text { sulfur }\end{array}$ & $\begin{array}{l}\text { Elemental } \\
\text { sulfur }\end{array}$ & $\begin{array}{r}\text { Sulfate } \\
\text { sulfur }\end{array}$ & $\begin{array}{l}\text { Bitumen } \\
\text { sulfur }\end{array}$ & $\begin{array}{c}\text { Kerogen } \\
\text { sulfur }\end{array}$ & $\%$ yield \\
\hline \multicolumn{9}{|l|}{ 146-893A- } \\
\hline IH-1, 82-98 & 0.9 & 65.2 & 6.6 & 2.3 & 16.0 & 2.1 & 7.8 & 79.6 \\
\hline $2 \mathrm{H}-7,62-80$ & 15.6 & 62.9 & 16.9 & 0.0 & 14.2 & 0.9 & 5.2 & 82.6 \\
\hline $5 \mathrm{H}-5,7 \mathrm{I}-77$ & 41.1 & 45.0 & 29.7 & 1.0 & 16.8 & 0.8 & 6.8 & 76.1 \\
\hline $7 \mathrm{H}-3,103-128$ & 55.9 & 33.7 & 31.6 & 16.2 & 6.5 & 1.3 & 10.7 & 80.1 \\
\hline $10 \mathrm{H}-4,45-59$ & 87.4 & 44.2 & 12.1 & 10.8 & 21.9 & 2.5 & 8.5 & 88.0 \\
\hline $13 \mathrm{H}-6,44-55$ & 117.0 & 45.0 & 21.3 & 2.8 & 20.1 & 1.4 & 9.5 & 87.7 \\
\hline $16 \mathrm{H}-3,26-40$ & 142.4 & 79.9 & 8.8 & 0.4 & 5.4 & 0.5 & 5.0 & 87.8 \\
\hline $17 \mathrm{H}-3,110-122$ & 153.1 & 62.1 & 12.0 & 0.3 & 20.0 & 0.7 & 4.9 & 79.7 \\
\hline $19 \mathrm{H}-5,66-77$ & 174.5 & 39.0 & 42.4 & 4.5 & 0.4 & 1.2 & 12.5 & 77.8 \\
\hline $21 \mathrm{H}-4,124-136$ & 192.3 & 32.8 & 39.9 & 0.5 & 23.1 & 0.3 & 3.3 & 87.3 \\
\hline
\end{tabular}

A

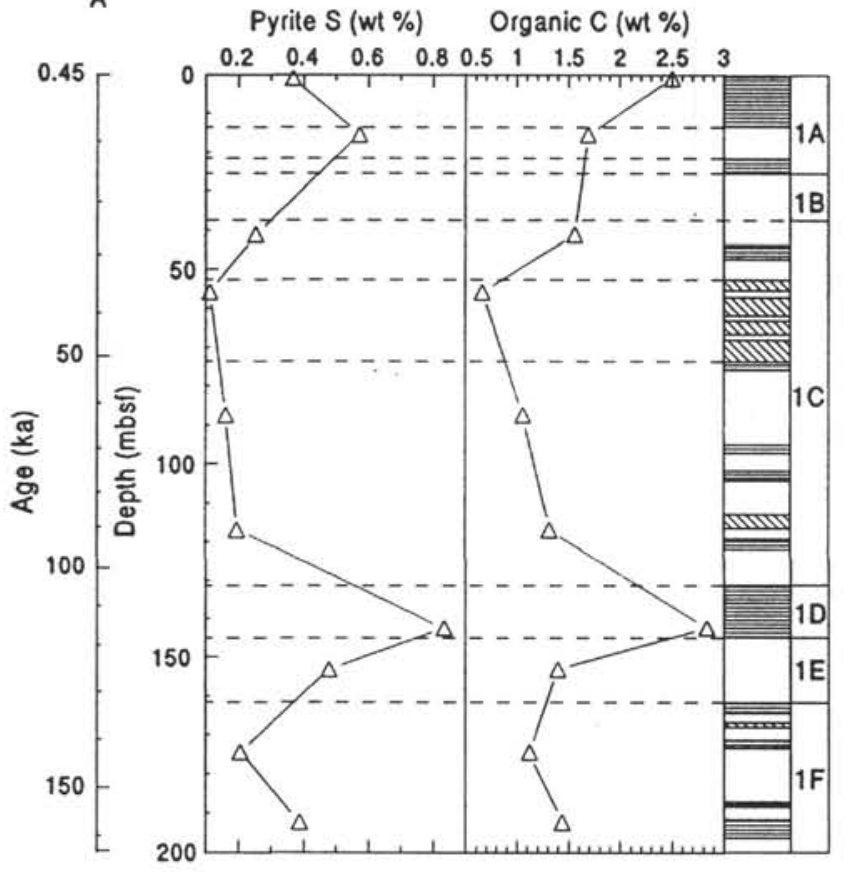

B

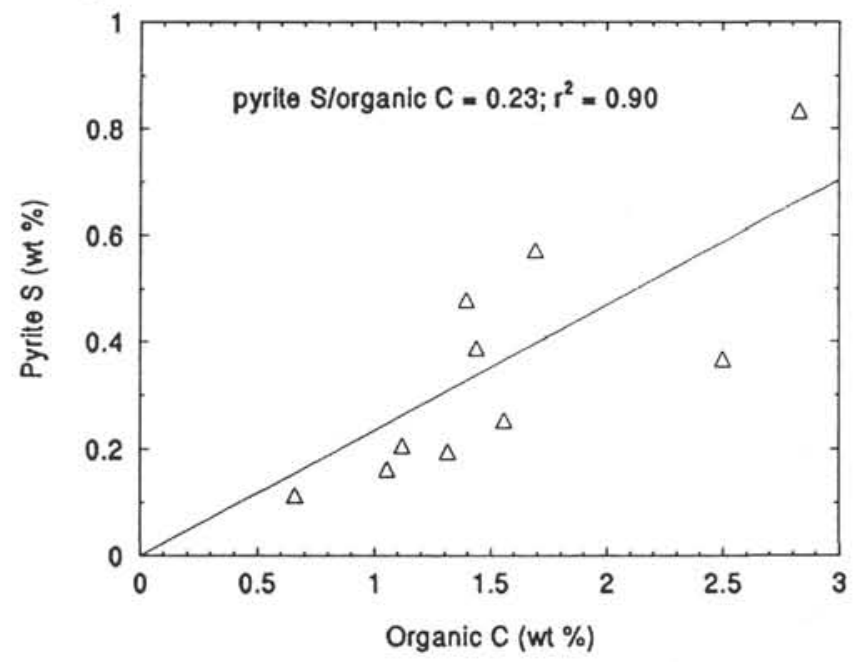

Figure 4. A. Stratigraphic variation in abundance of pyrite sulfur and organic carbon. Columns on the right as in Figure 3. B. Linear relationship between organic carbon and pyrite sulfur. Abundances of pyrite are interpreted to record abundances of metabolizable organic carbon suggesting that most pyrite formed in the uppermost meters.

lated with abundances of pyrite sulfur and organic carbon contents (Fig. 6A, B). Abundances of bitumen and kerogen sulfur have been normalized to organic carbon, because it serves as the substrate for organic sulfur. Experimental work (LaLonde et al., 1987; De Graaf et al., 1992; Fukushima et al., 1992; Rowland et al., 1993; Schouten et al., 1994) and studies of organic sulfur abundances in natural environments (Aizenshtat et al., 1983; Ferdelman et al., 1991; Mossmann et al., 1991; Schimmelmann and Kastner, 1993; Raiswell et al., 1993; Aplin and Macquaker, 1993; Kohnen et al., 1993) suggest that organic sulfur formation takes place preferentially in environments where hydrogen sulfide derived from bacterial sulfate reduction is reoxidized to intermediate species such as thiosulfate, sulfite, and polysulfides. In contrast, in sediments deposited under euxinic conditions concentration of partially oxidized species remains low and formation of organic sulfur may be less significant (Aplin and Macquaker, 1993; Raiswell et al., 1993). Episodic increases in the level of benthic oxygenation may be a key to understanding differential partitioning of sulfur into pyrite and organic matter for samples from Hole 893A. During intervals of increased oxygenation some of the bacterially reduced sulfur would have been reoxidized in the uppermost centime- 


\section{Pyrite S/Organic C}

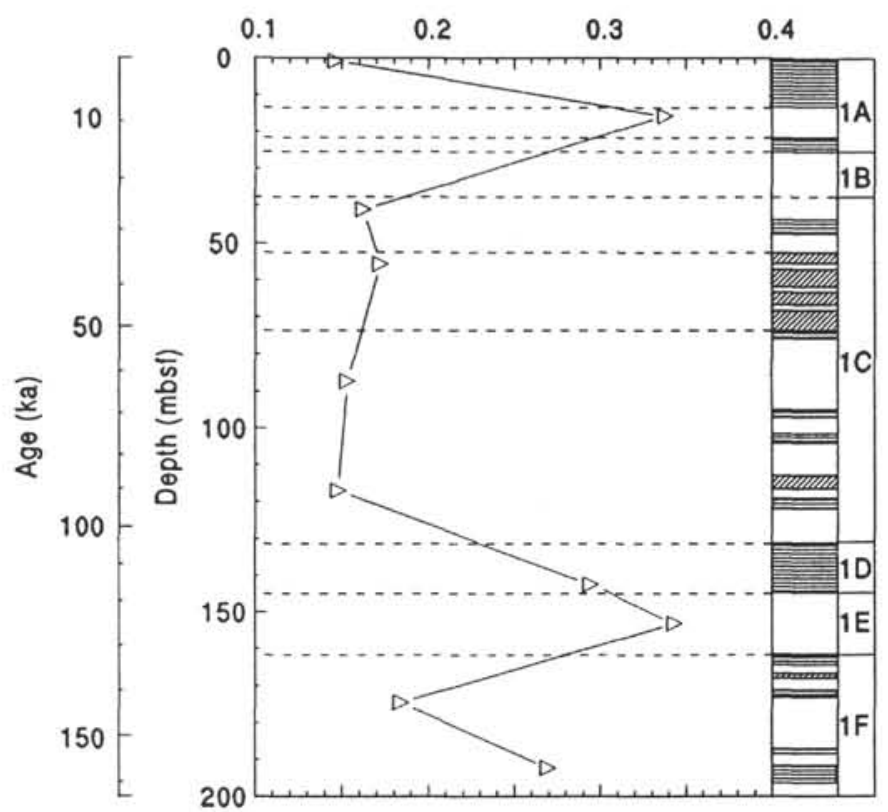

Figure 5. Stratigraphic variation of the ratio of pyrite sulfur to organic carbon. Variation in this ratio indicates different degrees of sulfur retention as pyrite, which may be related to changes in depositional conditions recorded in Hole 893A. Columns on the right as in Figure 3.

\section{Org. C (wt \%) Bit.S/C $C_{\alpha g}$ Elem. S (wt \%)}

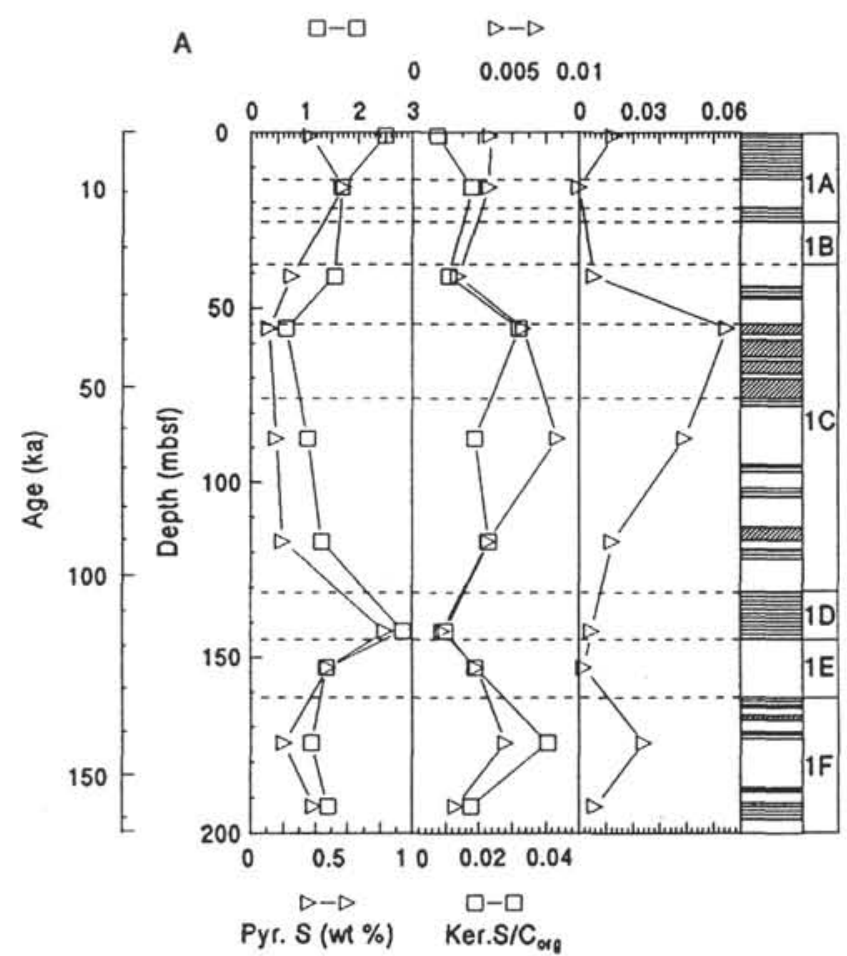

ters, either by reduction of manganese and/or iron, or by oxygen (Burdige, 1993; Thamdrup et al., 1994; Schulz et al., 1994).

Hydrogen sulfide may have been oxidized also by Beggiatoa spp., a sulfide-oxidizing bacterial mat known to exist at the present sediment-water interface in the Santa Barbara Basin (Soutar and Crill, 1977; Reimers et al., 1990; Grant, 1991; Schimmelmann and Kastner, 1993). Increased abundances of elemental sulfur at stratigraphic levels with higher abundances of organic sulfur may record sediments inhabited by sulfide-oxidizing bacterial mats. Since bacterial sulfate reducers are unable to reduce sulfate to elemental sulfur (Jørgensen, 1988), elemental sulfur is most likely derived from oxidation of sulfide. Bacterial sulfide oxidizers are known to produce polysulfides and thiosulfate (Nelson et al., 1986; Jørgensen, 1988). Beggiatoa spp. stores sulfur as minute polythionate droplets in invaginations of the bacterial cell membrane (Grant, 1991; Steudel et al., 1987).

During time periods of increased benthic oxygenation, the Beggiatoa bacterial mat may have migrated deeper into the sediment following the oxic-anoxic interface (Grant, 1991) and to escape destruction by benthic grazers below the zone of bioturbation. Shell fragments suggesting the presence of benthic grazers are reported from bioturbated and structureless stratigraphic intervals of Hole $893 \mathrm{~A}$ (Behl, this volume). Bacterial biomass derived from Beggiatoa spp. may represent an additional source of metabolizable organic carbon. The undegraded nature of the bacterial biomass may be conducive to reaction with dissolved, partially oxidized sulfur species to form organic sulfur compounds. Further studies are required to define the characteristics of the sulfurized organic matter and determine the biomolecular precursors.

Low abundances of elemental sulfur in laminated intervals are inferred to result from anoxic conditions where elemental sulfur and transient partially oxidized dissolved sulfur species are consumed during later burial. Higher levels of benthic oxygenation (bioturbated and structureless intervals) may favor preservation of elemental sul-

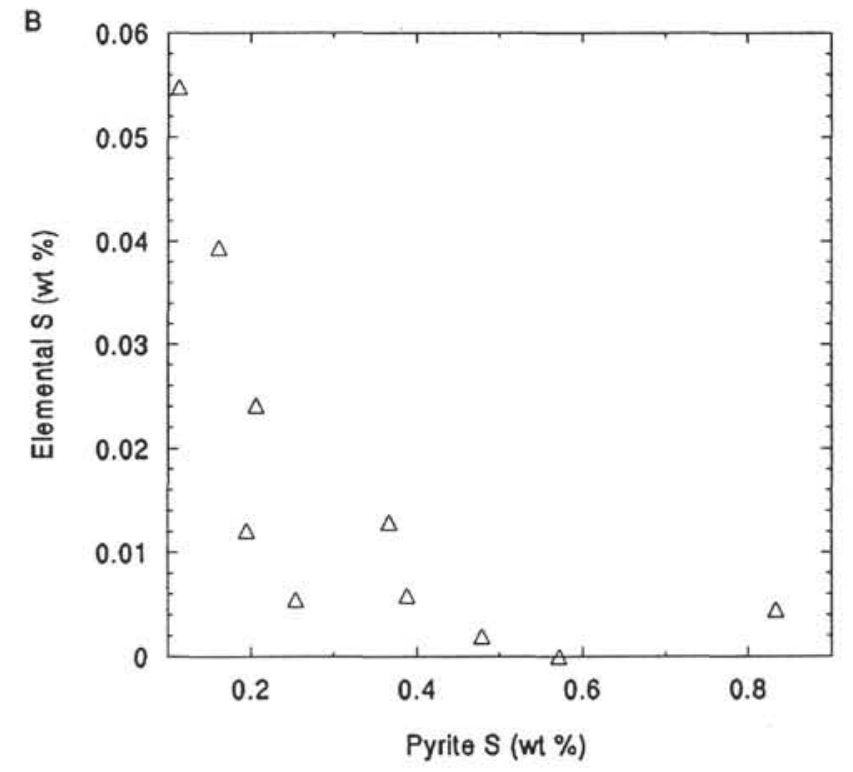

Figure 6. A. Stratigraphic variation in abundance for bitumen and kerogen sulfur normalized to organic carbon content, and stratigraphic variation of elemental sulfur. Comparison with stratigraphic variation in abundance of pyrite sulfur and organic carbon shows negative correlation for abundances of organic carbon and pyrite sulfur when compared with organic and elemental sulfur. Columns on right side as in Figure 3. B. Negative relationship between abundances of organic carbon and elemental sulfur. Similar relationships exist for plots of pyrite sulfur versus organic and elemental sulfur. 


\section{Pyr. S (wt \%) AVS (wt \%) Sulfate (wt \%)}

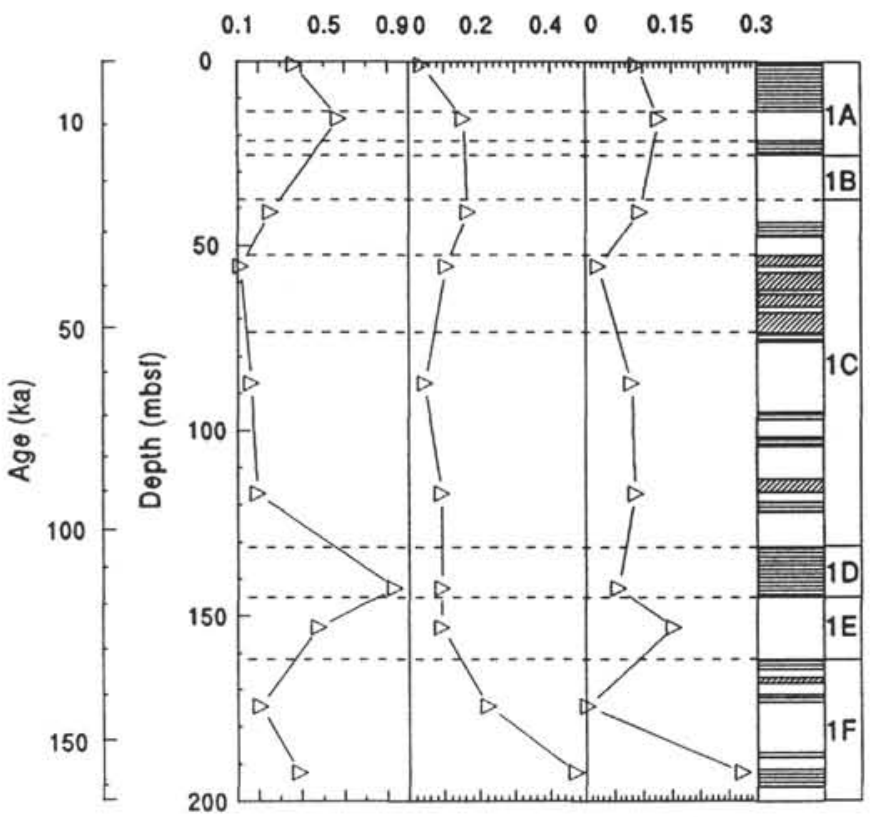

Figure 7. Stratigraphic variation in abundance of acid-volatile and sulfate sulfur compared with stratigraphic variation in abundance of pyrite sulfur. Abundances of acid-volatile sulfur and pyrite sulfur are not related. Columns on right side as in Figure 3.

fur and incorporation of sulfur into organic matter. This process may take place at the expense of pyrite formation. In contrast, laminated intervals, representing lower levels of benthic oxygenation, appear to have favored the incorporation of sulfide into pyrite.

\section{Acid-volatile Sulfur and Sulfate Sulfur}

Abundances of acid-volatile sulfur do not covary with abundances of pyrite sulfur (Fig. 7). There is no clear relationship between abundances of acid-volatile sulfides and lithologic variation. Abundances of acid-volatile and of pyrite sulfur are equal in Samples 893A-7H-3, 103-128 cm, 893A-19H-5, 66-77 cm, and 893A-21H-4, $124-136 \mathrm{~cm}$ (Table 3 ). Acid-volatile monosulfides may constitute intermediate products in the formation of pyrite and are often described as precursors to pyrite (e.g., Berner, 1970; Goldhaber and Kaplan, 1974; Canfield and Raiswell, 1992). Generally high abundances of acid-volatile sulfur suggest continuing formation or stability in the cored stratigraphic interval.

Abundances of sulfate sulfur constitute up to 23 percent of total sulfur abundances (Table 3 ). The extracted sulfate fraction includes sulfate precipitates from pore waters and dissolved, reoxidized metastable sulfur species such as thiosulfate, polythionates and polysul- fides (Amaral et al., 1993; Fossing and Jørgensen, 1990). Alternatively, the presence of sulfate may reflect laboratory dissolution of soluble sulfate minerals like celestite $\left(\mathrm{SrSO}_{4}\right)$ or gypsum $\left(\mathrm{CaSO}_{4} \cdot 2 \mathrm{H}_{2} \mathrm{O}\right)$. Acid-resistant sulfates like barite $\left(\mathrm{BaSO}_{4}\right)$ do not dissolve in the procedure used to remove acid-volatile sulfur.

\section{Sulfur Isotopes}

\section{Background: Sulfur Isotope Systematics}

The sulfur isotopic composition of individual species is controlled by the interplay of biological and physicochemical processes: (1) well-documented fractionation effects associated with dissimilatory sulfate reduction (Chambers and Trudinger, 1979) and with bacterially mediated or chemical oxidation of sulfide (Fry et al., 1988); (2) fractionation effects related to rates of bacterial sulfate reduction and availability of reactive organic carbon (Goldhaber and Kaplan, 1980); (3) fractionation effects related to differential diffusion gradients because of preferential uptake of the light isotope ${ }^{32} \mathrm{~S}$ (Goldhaber and Kaplan, 1980; Chanton et al., 1987); (4) the mass balance between sulfate import, sulfur retention and sulfur loss (Zaback et al., 1993); (5) recycling of bacterially reduced hydrogen sulfide because of disproportionation of thiosulfate (Jørgensen, 1990); and (6) different reaction kinetics in the formation of the various solid sulfur species (Canfield et al., 1992; Raiswell et al., 1993).

\section{Stratigraphic Variation in Isotopic Abundance of Sulfur Species}

Although only two sediments were analyzed for sulfur isotopic composition in interval $1 \mathrm{~A}$, composition and isotopic variation of the extracted species suggest conditions of formation different from the deeper sediments. Sedimentary structures and general lithology of the uppermost sedimentary interval suggest relatively uniform depositional conditions and permit comparison of these samples. Isotopic compositions of extracted sulfur species are listed in Table 4. Low $\delta$ values of pyrite indicate that only a fraction of sulfate transported into the sediment was retained as pyrite. There is no significant difference between the isotopic composition of pyrite in the uppermost two samples (Fig. 8). Assuming pyrite dominantly forms within a few meters of the sediment-water interface, then similar isotopic compositions of pyrite from these two samples suggest comparable benthic and diagenetic conditions.

In contrast to pyrite, isotope compositions of acid-volatile, bitumen and kerogen sulfur increase downward for the upper two samples in interval IA (Figs. 8, 9; Table 4). Abundance of elemental sulfur in Sample 893A-2H-7, 62-80 cm, was too low to analyze for sulfur isotopic composition. In the uppermost sample, acid-volatile, bitumen and kerogen sulfur are enriched in ${ }^{34} \mathrm{~S}$ to varying degrees relative to pyrite. Higher isotopic values suggest either uptake of sulfur from a pool enriched in ${ }^{34} \mathrm{~S}$ or a different precursor enriched in ${ }^{34} \mathrm{~S}$ such as primary organic sulfur with an isotopic composition close to seawater (Goldhaber and Kaplan, 1974; Francois, 1987).

Downward decrease in the isotopic composition of the extracted sulfate fraction from $20.1 \%$ to $10.6 \%$ vs. CDT in the uppermost two

Table 4. Isotopic composition of extracted sulfur species, Hole 893A.

\begin{tabular}{|c|c|c|c|c|c|c|c|}
\hline $\begin{array}{l}\text { Core, section, } \\
\text { interval }(\mathrm{cm})\end{array}$ & $\begin{array}{l}\text { Depth } \\
\text { (mbsf) }\end{array}$ & $\begin{array}{l}\delta^{4} S_{\text {pyrite }} \\
\%_{0} \text { CDT }\end{array}$ & $\begin{array}{l}\delta^{34} S_{\text {Avs }} \\
\%_{0} \text { CDT }\end{array}$ & $\begin{array}{l}\delta^{34} S_{\text {elem. }} \mathrm{s} \\
\% \circ \text { CDT }\end{array}$ & $\begin{array}{l}\delta^{34} S_{\text {sulfiate }} \\
\% \circ \mathrm{CDT}\end{array}$ & $\begin{array}{l}\delta^{24} S_{\text {kenogen }} \\
\% \text { CDT }\end{array}$ & $\begin{array}{l}\delta^{34} S_{\text {bitumen }} \\
\%_{0} \mathrm{CDT}\end{array}$ \\
\hline \multicolumn{8}{|l|}{$146-893 \mathrm{~A}=$} \\
\hline IH-1, 82-98 & 0.9 & -27.4 & -17.4 & -20.7 & 20.1 & -2.6 & 1.7 \\
\hline $2 \mathrm{H}-7,62-80$ & 15.6 & -28.9 & -1.7 & & 10.6 & 6.8 & 4.6 \\
\hline $5 \mathrm{H}-5,7 \mathrm{I}-77$ & 41.1 & -34.8 & 6.2 & -17.6 & -9.8 & 1.2 & 3.2 \\
\hline $7 \mathrm{H}-3,103-128$ & 55.9 & -20.7 & -11.0 & -19.2 & -9.2 & & 2.8 \\
\hline $10 \mathrm{H}-4,45-59$ & 87.4 & -35.5 & -5.4 & -4.1 & -12.1 & & \\
\hline $13 \mathrm{H}-6,44-55$ & 117.0 & -39.0 & -33.7 & -22.1 & -19.3 & & 0.6 \\
\hline $16 \mathrm{H}-3,26-40$ & 142.4 & -35.4 & -13.4 & 6.7 & 6.6 & 3.0 & 2.1 \\
\hline $17 \mathrm{H}-3,110-122$ & 153.1 & -24.1 & -12.1 & -16.2 & -19.6 & 2.0 & 2.3 \\
\hline $19 \mathrm{H}-5,66-77$ & 174.5 & -15.4 & -3.2 & -13.6 & -4.5 & & 0.4 \\
\hline $21 \mathrm{H}-4,124-136$ & 192.3 & -25.9 & 0.9 & 13.4 & 21.7 & 5.0 & 4.1 \\
\hline Fo range & & 23.6 & 39.9 & 35.5 & 41.3 & 9.4 & 4.2 \\
\hline
\end{tabular}




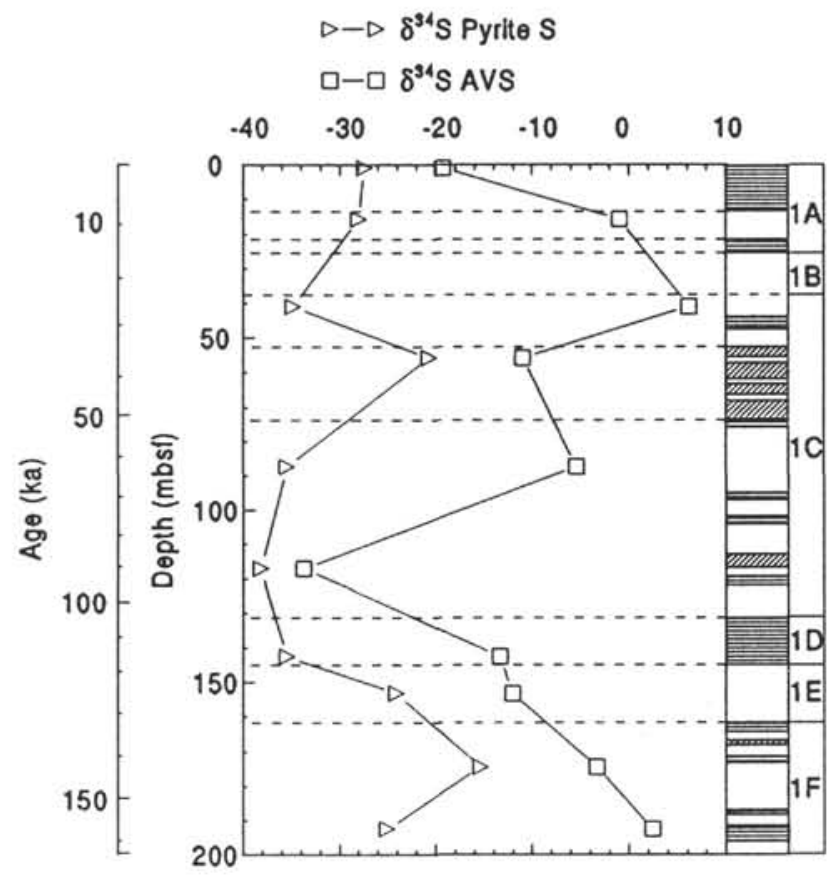

Figure 8. Stratigraphic variation of sulfur isotopic composition of pyrite and acid-volatile sulfur. Consistently heavier isotopic compositions of acid-volatile sulfur indicate different times of formation or separate geochemical pathways for the formation of these species. Columns on right side as in Figure 3.

samples is in conflict with a model of simple sulfate diffusion from the sediment/water interface and continuous enrichment of sulfate in ${ }^{34} \mathrm{~S}$ because of bacterial sulfate reduction (Goldhaber and Kaplan, 1980). The sulfate fraction appears to have an additional component possibly derived from oxidation of ${ }^{34} \mathrm{~S}$-depleted sulfide during diagenesis. Alternatively, dissolved hydrogen sulfide and intermediate species such as thiosulfate, polythionates, and polysulfides may have

A

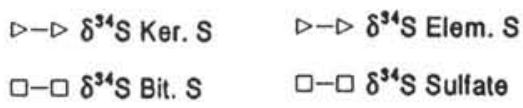

$\begin{array}{llllllllll}-2 & 0 & 2 & 4 & 6 & -20 & -10 & 0 & 10 & 20\end{array}$

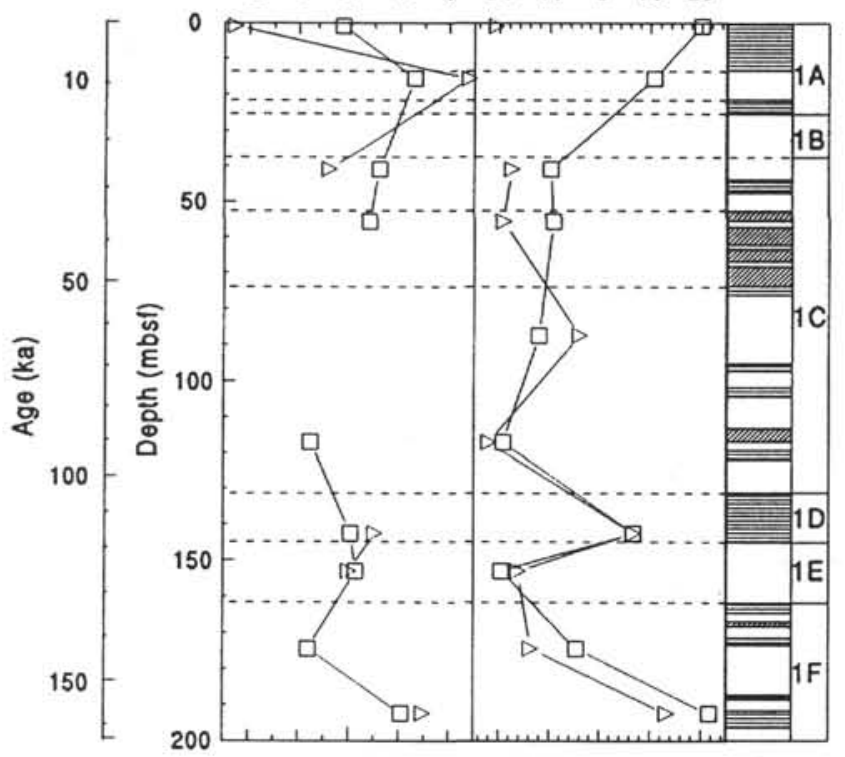

been oxidized during extraction or storage and are potentially present in our extracted sulfate fraction. Low isotopic values of these species may contribute to the downward decrease in the isotopic composition of the extracted sulfate fraction in the uppermost two samples.

Isotopic variations $(\Delta)$ between sulfur species may be used to constrain a depth at which the sulfur system has reached equilibrium or steady-state. Table 5 and Figure 10 show that only bitumen and kerogen sulfur show a narrow range of isotopic differences throughout the drilled stratigraphic interval. Formation of these two species is apparently closely linked both in time and space. Acid-volatile sulfur and pyrite sulfur show substantial variation in isotopic composition (Fig. 8). Abundances and isotopic compositions of acid-volatile sulfur compared to pyrite suggest either that acid-volatile sulfur was formed from a more evolved sulfide pool than pyrite, or that these two species derive from separate geochemical pathways. The data do not preclude that some acid-volatile sulfur is a precursor to pyrite. However, the fraction of acid-volatile sulfur that will form pyrite cannot be present at the same stratigraphic level as existent pyrite or is small compared to the remaining pool of isotopically enriched acidvolatile sulfur.

Isotopic abundances and stratigraphic variation of extracted sulfate and elemental sulfur are remarkably similar below a depth of 120 $\mathrm{m}$ (Table 5, Fig. 9). Generally low isotopic values of extracted sulfate indicate either bacterial or chemical oxidation during diagenesis of ${ }^{34} \mathrm{~S}$-depleted hydrogen sulfide to sulfate and intermediate species such as polysulfides and polythionates. Alternatively, these species were oxidized during storage and/or in our laboratory procedure and included to the extracted sulfate fraction. If partially oxidized dissolved sulfur species are precursors of elemental sulfur, then they may be responsible for the isotopic similarity between sulfate sulfur and elemental sulfur.

\section{Relationship Between Sulfur Isotopic Composition, Relative Abun- dance of Sulfur Species and Lithologic Variation}

Systematic relationships between sulfur isotopic composition, relative abundance of sulfur species, and lithological variation exist only below interval IC. Overall, correlation between sedimentologi-

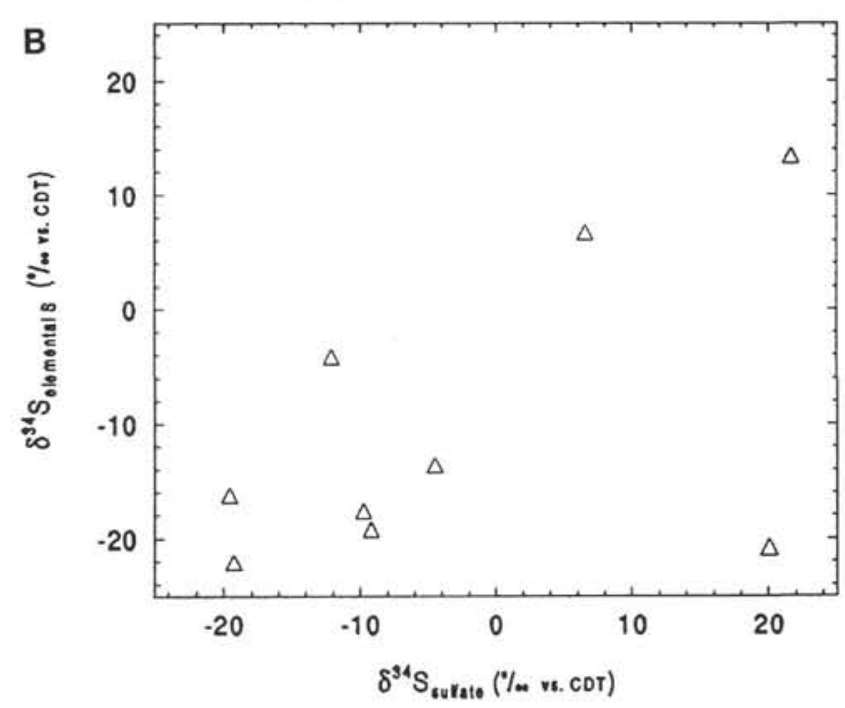

Figure 9. A. Stratigraphic variation in sulfur isotopic composition of bitumen, kerogen, elemental, and sulfate sulfur. Columns on right side as in Figure 3. B. Correlation of sulfur isotopic composition of extracted sulfate fraction and elemental sulfur suggesting a single source or partitioning of common components during the extraction procedure. 
Table 5. Isotopic differences of sulfur species relative to pyrite, Hole 893A.

\begin{tabular}{lrrrrrc}
\hline $\begin{array}{c}\text { Core, section, } \\
\text { interval (cm) }\end{array}$ & $\begin{array}{c}\text { Depth } \\
\text { (mbsf) }\end{array}$ & $\begin{array}{c}\Delta \\
\text { Acid-vol. S }\end{array}$ & $\begin{array}{c}\Delta \\
\text { Elemental S }\end{array}$ & $\begin{array}{c}\Delta \\
\text { Sulfate }\end{array}$ & $\begin{array}{c}\Delta \\
\text { Kerogen S }\end{array}$ & $\begin{array}{c}\Delta \\
\text { Bitumen S }\end{array}$ \\
\hline 146-893A- & & & & & & \\
IH-1, 82-98 & 0.9 & 1.0 & 6.7 & 47.5 & 24.8 & 29.1 \\
$2 \mathrm{H}-7,62-80$ & 15.6 & 27.3 & & 39.6 & 35.8 & 33.6 \\
$5 \mathrm{H}-5,71-77$ & 41.1 & 41.1 & 17.3 & 25.1 & 36.0 & 38.0 \\
$7 \mathrm{H}-3,103-128$ & 55.9 & 9.7 & 1.5 & 11.5 & & 23.5 \\
$10 \mathrm{H}-4,45-59$ & 87.4 & 30.1 & 31.4 & 23.4 & & 39.4 \\
$13 \mathrm{H}-6,44-55$ & 117.0 & 5.3 & 16.9 & 19.7 & 38.5 & 37.5 \\
$16 \mathrm{H}-3,26-40$ & 142.4 & 22.0 & 42.2 & 42.0 & 3.6 & 26.4 \\
$17 \mathrm{H}-3,110-122$ & 153.1 & 12.0 & 7.9 & 4.6 & 26.1 & 15.8 \\
$19 \mathrm{H}-5,66-77$ & 174.5 & 12.1 & 1.8 & 10.9 & 30.9 & 30.0 \\
$21 \mathrm{H}-4,124-136$ & 192.3 & 26.9 & 39.3 & 47.6 & 30.9 & \\
\hline
\end{tabular}

Note: $\Delta={ }^{34} \mathrm{~S}_{\text {ppecies }}-\Delta^{34} \mathrm{~S}_{\text {pyrite }}$

cal variation and isotopic composition of sulfur is less clear than expected. Difficulties in relating these parameters for intervals $1 \mathrm{~A}$ through $1 \mathrm{C}$ may result from ongoing diagenesis in the upper intervals and poorly understood characteristics of the diagenetic sulfur cycle.

It has been proposed that isotopic fractionation of sulfate may be inversely proportional to the rate of dissimilatory sulfate reduction (Kaplan et al., 1963; Goldhaber and Kaplan, 1980). Since pyrite frequently dominates reduced sulfur species in many marine sediments, sulfur isotopic composition of pyrite may be used to infer past rates of sulfate reduction (Goldhaber and Kaplan, 1974). Higher $\delta$-values of pyrite are interpreted to reflect increased rates of sulfate reduction whereas low isotopic values of pyrite are interpreted to reflect slower rates of sulfate reduction. In this study pyrite is always the species most depleted in ${ }^{34} \mathrm{~S}$ (Tables 4,5 ), suggesting it was the first reduced sulfur species formed. Isotopic compositions of pyrites would suggest that rates of sulfate reduction varied widely and were not related to a specific lithology (Fig. 8).

Below 120-m core depth, $\delta$-values of pyrites are higher in structureless and bioturbated sediments than in laminated sediments (Fig. 8). Samples with low abundances of pyrite and high abundances of organic sulfur have generally higher $\delta$-values for pyrite whereas samples with high abundances of pyrite and low abundances of organic sulfur have very low $\delta$-values for pyrites (Figs. 6A, 8). Conversely, sulfur isotopic compositions of bitumen and kerogen sulfur are more depleted in ${ }^{34} \mathrm{~S}$ in intervals with higher organic sulfur contents (Figs. $6,9 \mathrm{~A}$ ). Higher $\delta$-values of pyrite in samples with low abundances of pyrite require a sink for hydrogen sulfide competing with $\mathrm{Fe}^{2+}$. It is possible that organic and elemental sulfur were the ultimate sink for a fraction of hydrogen sulfide that was not used for pyrite formation. Consequently, incorporation of sulfur into organic matter had to begin very early during diagenesis. In contrast, higher $\delta$-values of sulfur in the organic, elemental, and extracted sulfate fraction in laminated sediments correspond to proportionally more uptake of ${ }^{34} \mathrm{~S}$-depleted sulfide into pyrite. Possibly, reoxidation and recycling of hydrogen sulfide was less significant in these time intervals and pyrite was the dominant sink for reduced sulfur.

An alternative explanation for the high $\delta$-values of kerogen and bitumen sulfur would be that sulfur contained in these two fractions is derived from labile primary organic sulfur with an isotopic composition close to seawater. Degradation of labile sulfur-containing biomolecules during diagenesis releases isotopically enriched sulfide (Goldhaber and Kaplan, 1974; Francois, 1987). Primary organic sulfur may take part in similar oxidative pathways as bacterially produced hydrogen sulfide, changing the initial isotopic composition and producing the same partially oxidized reactive intermediates. Reaction of this isotopically enriched sulfide with organic molecules may be favored over uptake of externally produced sulfur because of shorter transport lengths of primary organic sulfur to reactive sites on the biomolecules.

\section{Sulfur Isotope Budget}

Calculation of the total sulfur isotopic composition from abundance and isotopic composition of individual sulfur species yields consistently lower values than the isotopic composition of seawater sulfate $\left(\delta^{34} \mathrm{~S}_{\mathrm{sw}}=20.4 \%\right.$ vs. CDT) (Table 6). Low isotopic values of total sulfur throughout the stratigraphic interval of Hole $893 \mathrm{~A}$ lindicate that only a fraction of sulfate entering the sediment was retained. In addition, $\delta^{34} \mathrm{~S}_{\text {total sulfur }}$ can be used to calculate two useful parameters, $\alpha_{0}$ and $f_{\mathrm{s}}$ :

$$
\alpha_{o}=\left(10^{3}+{ }^{34} S_{\mathrm{sw}}\right) /\left(10^{3}+\delta^{34} \mathrm{~S}_{\text {total sulfur }}\right) \text { and } f_{\mathrm{s}}=\left(\alpha_{o}-r_{r}\right) /\left(1-r_{r}\right) \text {, }
$$

where $\alpha_{0}$ represents the overall sulfur isotope fractionation associated with transport of sulfate/sulfide and bacterially mediated sulfate

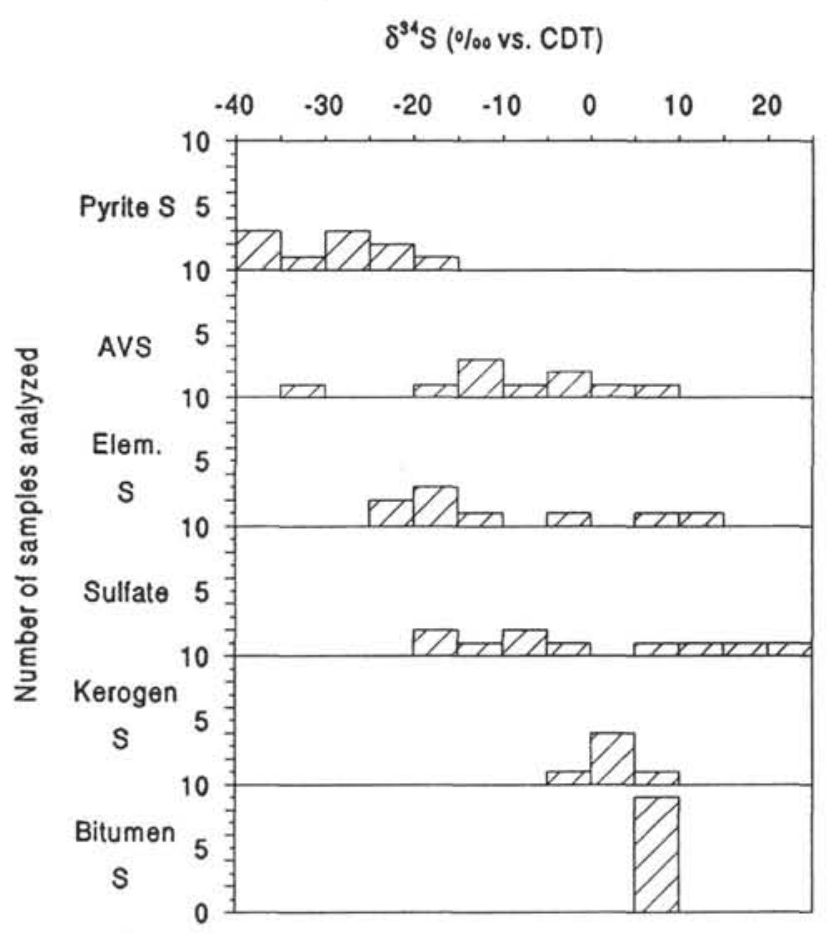

Figure 10. Frequency distribution of sulfur species for the 10 samples analyzed. Notable is the comparably narrow range in sulfur isotopic composition of bitumen and kerogen sulfur and the ${ }^{34} \mathrm{~S}$-depleted isotopic composition of pyrites. Contrasting wide variations in isotopic compositions of elemental, sulfate, and acid-volatile sulfur reflect complex geochemical pathways of sulfur during early diagenesis. 
Table 6. The $f_{s}$ values calculated to assess proportion of sulfur retained in the sediment relative to total amount of sulfur imported (Zaback et al., 1993) with stratigraphic variation of calculated isotopic composition of total sulfur.

\begin{tabular}{|c|c|c|c|c|}
\hline \multirow{2}{*}{$\begin{array}{l}\text { Core, section. } \\
\text { interval }(\mathrm{cm})\end{array}$} & \multirow{2}{*}{$\begin{array}{l}\text { Depth } \\
\text { (mbsf) }\end{array}$} & $\begin{array}{l}\text { General description } \\
\delta^{34} S^{*} \text { (mbsf) }\end{array}$ & \multirow[b]{2}{*}{$\alpha_{\mathrm{o}}$} & \multirow[b]{2}{*}{$f_{s}$} \\
\hline & & Total sulfur & & \\
\hline \multicolumn{5}{|l|}{ 146-893A- } \\
\hline IH-1, 82-98 & 0.9 & -16.4 & 1.037 & 0.38 \\
\hline $2 \mathrm{H}-7,62-80$ & 15.6 & -16.6 & 1.037 & 0.38 \\
\hline $5 \mathrm{H}-5,7 \mathrm{I}-77$ & 41.1 & -15.6 & 1.036 & 0.40 \\
\hline $7 \mathrm{H}-3,103-128$ & 55.9 & -14.2 & 1.035 & 0.42 \\
\hline $10 \mathrm{H}-4,45-59$ & 87.4 & -19.5 & 1.040 & 0.33 \\
\hline $13 \mathrm{H}-6,44-55$ & 117.0 & -29.2 & 1.051 & 0.16 \\
\hline $16 \mathrm{H}-3,26-40$ & 142.4 & -28.9 & 1.050 & 0.16 \\
\hline $17 \mathrm{H}-3.110-122$ & 153.1 & -20.3 & 1.041 & 0.31 \\
\hline $19 \mathrm{H}-5,66-77$ & 174.5 & -8.0 & 1.028 & 0.53 \\
\hline $21 \mathrm{H}-4,124-136$ & 192.3 & -2.9 & 1.023 & 0.62 \\
\hline
\end{tabular}

Note: *Inferred isotopic composition of total sulfur: ${ }^{34} \mathrm{~S}_{\mathrm{uns} \mathrm{s}}=\mathrm{X}_{\text {pyrite }} \times \delta^{24} \mathrm{~S}_{\text {pyrite }}+$

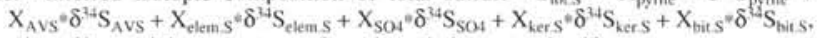
where $\mathrm{X}_{\mathrm{i}}=$ weight percentage of species relative to total sulfur.

reduction, $\alpha_{r}$ is the sulfur isotope fractionation factor associated with bacterial sulfate reduction, here taken as 1.06 from Chambers and Trudinger (1979), and $f_{\mathrm{s}}$ is a measure of the fraction of sulfate that was imported into the sediment and retained as sulfide (Zaback et al., 1993). These calculations give values of $f_{s}$ ranging between 0.16 and 0.62 (Table 6) and suggest that no more than 60 percent of the total amount of sulfur imported into the sediment was retained in a sulfur product. The wide range of $f_{s}$ values indicates strongly varying proportions of sulfur mass transport relative to bacterial sulfate reduction (Zaback et al., 1993). Additional data are required to explain the very low values of total sulfur and $f_{s}$ for Samples 893A$13 \mathrm{H}-6,44-55 \mathrm{~cm}$, and $893 \mathrm{~A}-16 \mathrm{H}-3,26-40 \mathrm{~cm}$. The low $\delta$-values of pyrite observed in these samples could be associated with euxinic benthic conditions (Fry et al., 1991; Beier and Hayes, 1989) or with diagenetic recycling of hydrogen sulfide involving disproportionation of partially oxidized intermediates (Jørgensen, 1990; Canfield and Thamdrup, 1994). Canfield and Thamdrup (1994) observed an enrichment in ${ }^{32} \mathrm{~S}$ in the hydrogen sulfide produced from disproportionation of elemental sulfur. Repeated cycles of reduction, reoxidation to elemental sulfur and disproportionation to hydrogen sulfide and sulfate (Jørgensen, 1990) may explain the isotopic depletion of the pyrites in these samples.

\section{CONCLUSIONS AND SUMMARY}

Abundances of pyrite and organic carbon covary throughout the drilled core. This relationship suggests that abundance of pyrite records the amount of most readily metabolizable organic matter. Comparably narrow range and low isotopic values of pyrites suggest formation in the uppermost meters of sediment. Linear decrease in abundances of organic carbon and corresponding increase in abundances of total sulfur in interval IA may indicate the depth interval of most substantial consumption of organic matter.

Data on abundance and isotopic composition of sulfur species suggest differential response of the sedimentary sulfur system to past degrees of benthic oxygenation. Under present-day conditions of low-oxygen bottom water, pyrite appears to dominate the early diagenetic products of reduced sulfur. However, at times of higher benthic oxygenation preservation of partially oxidized species as elemental and organic sulfur was more significant. In general, the amount of sulfur preserved as organic sulfur is small compared to widely referenced black shales rich in sulfur, like the Monterey Formation (Zaback and Pratt, 1992).
Low isotopic values of extracted sulfate are best explained by chemical or biological reoxidation of ${ }^{34} \mathrm{~S}$-depleted hydrogen sulfide. Extracted sulfate is most likely a composite of diffused seawater sulfate, sulfate derived from reoxidation of hydrogen sulfide in addition to potential contributions from acid-soluble sulfate minerals. Intermediate, metastable sulfur species such as polythionates, polysulfides, and thiosulfate may also have been reoxidized and included to the extracted sulfate fraction during storage and laboratory work-up. Abundances of these species in pore waters are generally low compared to sulfate and hydrogen sulfide (Luther et al., 1985, 1991; Thamdrup et al., 1994). Thus, these species will only have a minor influence on abundance and isotopic composition of the extracted sulfate. Isotopic similarity between elemental sulfur and the sulfate fraction suggests either that the two fractions have a single sourcepossibly recycled hydrogen sulfide-or that the components contained in the two fractions were fractionated during the extraction procedure.

Small range in isotopic composition and high sulfur isotopic values of kerogen sulfur and bitumen sulfur compared to other solid sulfur species suggest formation by a unique process, which appears to be restricted either to a narrow time/space interval or to the availability of undegraded reactive organic carbon. Possibly, sulfur in the organic fraction is derived from recycling of ${ }^{34} \mathrm{~S}$-enriched primary organic sulfur.

Currently, the number of analyzed samples of Hole 893A are insufficient to provide detailed information on relative timing and maximum depth of formation of diagenetic sulfur species.

\section{REFERENCES ${ }^{*}$}

Aizenshtat, Z., Stoler, A., Cohen, Y., and Nielsen, H., 1983. The geochemical sulphur enrichment of recent organic matter by polysulfides in the Solar Lake. In Bjorøy, M., Albrecht, C., Cornford, C., de Groot, K., Eglinton, G., et al. (Eds.), Advances in Organic Geochemistry, 1981. Proc. Int. Meet. Org. Geochem., 10:279-288.

Amaral, J.A., Kelly, C.A., and Flett, R.J., 1993. Measurements of organic${ }^{35} \mathrm{~S}$ and organic-S in lake sediments: methodological considerations. Biogeochemistry, 23:61-78.

Aplin, A.C., and Macquaker, J.H.S., 1993. C-S-Fe geochemistry of some modern and ancient anoxic marine muds and mudstones. Philos. Trans. R. Soc. London, 344:89-100.

Beier, J.A., and Hayes, J.M., 1989. Geochemical and isotopic evidence for paleoredox conditions during deposition of the Devonian-Mississippian New Albany Shale, southern Indiana. Geol. Soc. Am. Bull., 101:774-782.

Bein, A., Almogi-Labin, A., and Sass, E., 1990. Sulfur sinks and organic carbon relationships in Cretaceous organic-rich carbonates: implications for evaluation of oxygen-poor environments. Am. J. Sci., 290:882-911.

Berner, R.A., 1970. Sedimentary pyrite formation. Am. J. Sci., 268:1-23. 1984. Sedimentary pyrite formation: an update. Geochim. Cosmochim. Acta, 48:605-615.

Burdige, D.J., 1993. The biogeochemistry of manganese and iron reduction in marine sediments. Earth-Sci. Rev., 35:249-284.

Canfield, D.E., 1989. Reactive iron in marine sediments. Geochim. Cosmochim. Acta, 53:619-632.

Canfield, D.E., and Raiswell, R., 1992. Pyrite formation and fossil preservation. In Allison, P.A., and Briggs, D.E.G. (Eds.), Topics in Geobiology (Vol. 9): Taphonomy: Releasing the Data from the Fossil Record: New York (Plenum Press), 337-387.

Canfield, D.E., Raiswell, R., and Bottrell, S., 1992. The reactivity of sedimentary iron minerals toward sulfide. Am. J. Sci., 292:659-683.

Canfield, D.E., and Thamdrup, B., 1994. The production of ${ }^{34}$ S-depleted sulfide during bacterial disproportionation of elemental sulfur. Science, 266:1973-1975.

Chambers, L.A., and Trudinger, P.A., 1979. Microbiological fractionation of stable sulfur isotopes: a review and critique. Geomicrobiol. J., 1:249293.

Chanton, J.P., Martens, C.S., and Goldhaber, M.B., 1987. Biogeochemical cycling in an organic-rich coastal marine basin, 8. A sulfur isotope budget balanced by differential diffusion across the sediment-water interface. Geochim. Cosmochim. Acta, 51:1201-1208. 
Dean, W.E., and Arthur, M.A., 1989. Iron-sulfur relationships in organic-carbon-rich sequences, I. Cretaceous western interior seaway. Am. J. Sci., 289:708-743.

De Graaf, W., Sinninghe Damsté, J.S., and de Leeuw, J.W., 1992. Laboratory simulation of natural sulphurization, I. Formation of monomeric and oligomeric isoprenoid polysulphides by low-temperature reactions of inorganic polysulphides with phytol and phytadienes. Geochim. Cosmochim. Acta, 56:4321-4328.

Ferdelman, T., Church, T.M., and Luther, G.W., III, 1991. Sulfur enrichment of humic substances in a Delaware salt marsh sediment core. Geochim. Cosmochim. Acta, 55:979-988.

Fossing, H., and Jørgensen, B.B., 1990. Isotope exchange reaction with radiolabeled sulfur compounds in anoxic seawater. Biogeochemistry, 9:223245 ,

Francois, R., 1987. A study of sulfur enrichment in the humic fraction of marine sediments during early diagenesis. Geochim. Cosmochim. Acta, 51:17-27.

Fry, B., Gest, H., and Hayes, J.M., 1988. ${ }^{34} \mathrm{~S} /{ }^{32} \mathrm{~S}$ fractionation in sulfur cycles catalyzed by anacrobic bacteria. Appl. Environ. Microbiol., $54: 250-256$.

Fry, B., Jannasch, H.W., Molyneaux, S.J., Wirsen, C.O., Muramoto, J.A., and King, S., 1991. Stable isotope studies of the carbon, nitrogen and sulfur cycles in the Black Sea and the Cariaco trench. Deep-Sea Res., 38:1003-1019.

Fukushima, K., Yasukawa, M., Muto, N., Uemura, H., and Ishiwatari, R., 1992. Formation of $\mathrm{C}_{20}$ isoprenoid thiophenes in modern sediments. Org. Geochem., 18:93-91.

Goldhaber, M.B., and Kaplan, I.R., 1974. The sulfur cycle. In Goldberg, E.D. (Ed.), The Sea (Vol. 5): Marine Chemistry: The Sedimentary Cycle: New York (Wiley-Interscience), 569-655.

, 1980. Mechanisms of sulfur incorporation and isotope fractionation during early diagenesis in sediments of the Gulf of California. Mar. Chem., 9:95-143.

Grant, C.W., 1991. Distribution of bacterial mats (Beggiatoa spp.) in Santa Barbara Basin. California: a modern analog for organic-rich facies of the Monterey Formation [M.S. thesis]. California State Univ., Long Beach.

Hieshima, G.B., and Pratt, L.M., 1991. Sulfur/carbon ratios and extractable organic matter of the Middle Proterozoic Nonesuch Formation, North American Midcontinent Rift. Precambrian Res., 54:65-79.

Jørgensen, B.B., 1988. Ecology of the sulfur cycle: oxidative pathways in sediments. In Cole J.A., and Ferguson, S. (Eds.), The Nitrogen and Sulfur Cycles. Symp. Soc. Gen. Microbiol., 42:31-63.

, 1990. A thiosulfate shunt in the sulfur cycle of marine sediments. Science, 249:152-154.

Kaplan, I.R., Emery, K.O., and Rittenberg, S.C., 1963. The distribution and isotopic abundance of sulphur in Recent marine sediments. Geochim. Cosmochim. Acta, 27:297-331.

Kennett, J.P., Baldauf, J.G., et al., 1994. Proc. ODP, Init. Repts., 146 (Pt. 2): College Station, TX (Ocean Drilling Program).

Kohnen, M.E.T., Sinninghe Damsté, J.S., Baas, M., Kock-van Dalen, A.C., and de Leeuw, J.W., 1993. Sulphur-bound steroid and phytane carbon skeletons in geomacromolecules: implications for the mechanism of incorporation of sulphur into organic matter. Geochim. Cosmochim. Acta, 57:2515-2528.

Kohnen, M.E.T., Sinninghe Damsté, J.S., Rijpstra, W.I.C., and de Leeuw, J.W., 1990. Alkylthiophenes as sensitive indicators of paleoenvironmental changes: a study of a Cretaceous oil shale from Jordan. In Orr. W.L.. and White, C.M. (Eds.), Geochemistry of Sulfur in Fossil Fuels. ACS Symp. Ser., 429:444 485.

LaLonde, R.T., Ferrara, L.M., and Hayes, M.P., 1987. Low-temperature polysulfide reactions of conjugated ene carbonyls: a reaction model for the geologic origin of S-heterocycles, Org. Geochem., 11:563-571.

Luther, G.W., Ferdelman, T.G., Kostka, J.E., Tsamakis, E.J., and Church, T.M., 1991. Temporal and spatial variability of reduced sulfur species
$\left(\mathrm{FeS}_{2}, \mathrm{~S}_{2} \mathrm{O}_{3}{ }^{2-}\right)$ and porewater parameters in salt marsh sediments. Biogeochemistry, 14:57-88.

Luther, G.W., Giblin, A.E., and Varsolona, R., 1985. Polarographic analysis of sulfur species in marine porewaters. Limnol. Oceanogr., 30:727-736.

Middelburg, J.J., 1991. Organic carbon, sulphur, and iron in Recent semieuxinic sediments of Kau Bay, Indonesia. Geochim. Cosmochim. Acta. 55:815-828.

Mossmann, J.R., Aplin, A.C., Curtis, C.D., and Coleman, M.L., 1991. Geochemistry of inorganic and organic sulphur in organic-rich sediments from the Peru Margin. Geochim. Cosmochim. Acta, 55:3581-3595.

Nelson, D.C., Jørgensen, B.B., and Revsbech, N.P., 1986. Growth pattern and yield of a chemoautotrophic Beggiatoa spp. in oxygen-sulfide microgradients. Appl. Environ. Microbiol., 52:225-233.

Raiswell, R., and Berner, R.A., 1985. Pyrite formation in euxinic and semieuxinic sediments. Am. J. Sci., 285:710-724.

Raiswell, R., Bottrell, S.H., Al-Biatty, H.J., and Tan, M.Md., 1993. The influence of bottom water oxygenation and reactive iron content on sulfur incorporation into bitumens from Jurassic marine shales. Am. J.Sci., 293:569-596.

Raiswell, R., Buckley, F., Berner, R.A., and Anderson, T.F., 1988. Degree of pyritization of iron as a paleoenvironmental indicator of bottom-water oxygenation. J. Sediment. Petrol., 58:812-819.

Reimers, C.E., Lange, C.B., Tabak, M., and Bernhard, J.M., 1990. Seasonal spillover and varve formation in the Santa Barbara Basin, California. Limnol. Oceanogr., 35:1577-1585.

Rowland, S., Rockey, C., Al-Lihaibi, S.S., and Wolff, G.A., 1993. Incorporation of sulphur into phytol derivatives during simulated early diagenesis. Org. Geochem., 20:1-5.

Schimmelmann, A., and Kastner, M., 1993. Evolutionary changes over the last 1000 years of reduced sulfur phases and organic carbon in varved sediments of the Santa Barbara Basin, California. Geochim. Cosmochim. Acta, 57:67-78.

Schouten, S., van Driel, G.B., Sinninghe Damsté, J.S., and de Leeuw, J.W.. 1994. Natural sulphurization of ketones and aldehydes: a key reaction in the formation of organic sulphur compounds. Geochim. Cosmochim. Acta, 58:5111-5116.

Schulz, H.D., Dahmke, A., Schinzel, U., Wallmann, K., and Zabel, M., 1994. Early diagenetic processes, fluxes, and reaction rates in sediments of the South Atlantic. Geochim. Cosmochim. Acta, 58:2041-2060.

Soutar, A., and Crill, P.A., 1977. Sedimentation and climatic patterns in the Santa Barbara Basin during the 19th and 20th centuries. Geol. Soc. Am. Bull., 88:1161-1172.

Steudel, R., Holdt, G., Göbel, T., and Hazeu, W., 1987. Chromatographic separation of higher polythionates $\mathrm{S}_{n} \mathrm{O}_{6}{ }^{2-}(\mathrm{n}=3 \ldots 22)$ and their detection in cultures of Thiobacillus ferrooxidans: molecular composition and bacterial sulfur secretions. Angew. Chem., Int. Ed. Engl., 26:151-153.

Thamdrup, B., Finster, K., Fossing, H., Hansen, J.W., and Jørgensen, B.B., 1994. Thiosulfate and sulfite distributions in porewater of marine sediments related to manganese, iron, and sulfur geochemistry. Geochim. Cosmochim. Acta, 58:67-73.

Zaback, D.A., and Pratt, L.M., 1992. Isotopic composition and speciation of sulfur in the Miocene Monterey Formation: reevaluation of sulfur reactions during early diagenesis in marine environments. Geochim. Cosmochim. Acta, 56:763-774.

Zaback, D.A., Pratt, L.M., and Hayes, J.M., 1993. Transport and reduction of sulfate and immobilization of sulfide in marine black shales. Geology, 21:141-144.

Date of initial receipt: 2 August 1994

Date of acceptance: 8 February 1995

Ms 146SR-295 